\title{
Treatment with midazolam for nocturnal sedation of terminal cancer patients in a hospice setting
}

\author{
Hiroko Kouta $^{13)}$, Kazuhiko Hanada ${ }^{2)}$, Hiroyasu Ogata ${ }^{2)}$ \\ 1) Postgraduate Course of Clinical Pharmacy, Meiji Pharmaceutical University (Former institutional affiliation: Department of Hospital \\ Pharmacy, Kyuseigun Kiyose Hospital) \\ 2) Department of Biopharmaceutics and Clinical Pharmacokinetics, Meiji Pharmaceutical University \\ 3) Ohki Memorial Kikuchi Cancer Clinic for Women
}

Received 5/17/2007, revised 10/3/2007, accepted 10/12/2007

\begin{abstract}
Sleep disturbance often leads to physical and psychological distress and contributes to poor quality of life in terminal cancer patients. Midazolam is administered by continuous intravenous infusion in many Japanese palliative care units for the purpose of nocturnal sedation when patients cannot take oral medications or do not sufficiently respond to oral or per-rectal medication. However, there is insufficient data to assess optimal doses and other parameters for administration. In addition, the possibility of tolerance to midazolam reported in several studies is a further limitation. The present study retrospectively surveyed inpatient hospice experience in 19 patients who were prescribed midazolam in an attempt to induce nocturnal sedation. The midazolam infusion rate used for the longest period each day to maintain appropriate sleep without oversadation and with clear arousal on the following morning was defined as the "maintenance dose". Midazolam maintenance doses of 2 patients were greatly increased during their treatment period. Statistical analysis was then conducted in the other 17 patients using NONMEM software to analyze time-dependent changes in maintenance doses and possible associated factors. However, in the other 17 patients no significant timedependent changes were observed during midazolam treatment. It would suggest that torerance may not be induced by intermittent administration of midazolam. Midazolam maintenance doses were significantly greater in patients treated with haloperidol. Palliat Care Res 2007;2(2):211-217
\end{abstract}

Keywords: midazolam, terminal cancer, hospice, sedation, intravenous administration

\section{Introduction}

Sleep disturbance often leads to physical and psychological distress, including fatigue and sleepiness in the daytime, which can interfere with the ability of patients to function normally, and contributes to a decline in quality of life [1]. It is particularly important to alleviate stress for terminal cancer patients as much as possible by ensuring sufficient quality and quantity of sleep.

Intravenous administration of benzodiazepines is suitable for patients who cannot take oral medications due to gastrointestinal cancer or other cancers in head and neck, and for patients who do not sufficiently respond to oral or per-rectal benzodiazepine preparations. In Japan midazolam has been empirically administered to ensure nighttime sleep in many palliative care units; nevertheless, optimal doses and other parameters for administration have not been established [2].

Midazolam produces a hypnotic and sedative effect and is commonly used as an anesthetic induction agent and as an intravenous agent for sedation in the ICU [3-9]. In the field of palliative medicine, midazolam has been administered by continuous infusion intravenously or subcutaneously to ease terminal uncontrollable symptoms such as delirium, nausea and vomiting, dyspnea, and fatigue [10-12].
When midazolam is used as an agent for nocturnal sedation both sufficient nighttime sleep and arousal upon awakening the next day must be ensured. Midazolam appears to be suitable for administration by continuous infusion for nocturnal sedation, because it has be characterized by relatively rapid onset of action and short recovery time. While it is possible that tolerance may develop during continuous long-term use of midazolam [4,10-12], it has not been reported, as far as we know, whether tolerance develops during repeated intermittent short-term infusion for insomnia. In the present study, patients with terminal cancer treated with midazolam infusion were retrospectively surveyed to assess the optimal infusion rates of midazolam needed to maintain appropriate sleep without oversedation and with clear arousal on the following morning. Statistical analysis was conducted to analyze time-dependent changes in maintenance doses and possible associated factors.

\section{Materials and methods}

The study examined the clinical response of 19 patients (mean age $62.4 \pm 14.3$ years) admitted to a hospice unit in Kyuseigun Kiyose Hospital between January 2002 and March 2006 who were treated with midazolam by continuous, intravenous infusion for induction of sedation from night to morning. Patients included 
Table 1. Patient characteristics

\begin{tabular}{|c|c|c|c|c|c|c|c|c|}
\hline $\begin{array}{l}\text { Patient } \\
\text { No. }\end{array}$ & Sex & Age & $\begin{array}{c}\text { Assessment } \\
\text { period } \\
\text { (days) }\end{array}$ & $\begin{array}{l}\text { Primary } \\
\text { tumor site }\end{array}$ & Metastatic sites of tumor & $\begin{array}{l}\text { Predominant } \\
\text { signs and } \\
\text { symptoms }\end{array}$ & $\begin{array}{l}\text { Opioid } \\
\text { maximum } \\
\text { dose } \\
\text { (mg/day) }\end{array}$ & $\begin{array}{c}\text { Concomitant } \\
\text { psychotropics }\end{array}$ \\
\hline 1 & $M$ & 78 & 7 & Lung & Bone & Dys & 0 & - \\
\hline 2 & M & 78 & 36 & Thyroid & Bone & Asc $\cdot$ Pain & 25.5 & - \\
\hline 3 & $\mathrm{~F}$ & 47 & 30 & Lung & Bone $\cdot$ Pericardium $\cdot$ Pleura & Dys $\cdot \mathrm{Ple} \cdot \mathrm{Nau}$ & 40 & HAL/LEV/BRM (3mg/day) \\
\hline 4 & $\mathrm{~F}$ & 57 & 10 & Ovary & Liver $\cdot$ Peritoneum $\cdot$ Lymph node & $\mathrm{Ple} \cdot \mathrm{Nau}$ & 45 & HAL/BRM (3mg/day) \\
\hline 5 & M & 72 & 15 & Stomach & Peritoneum & Asc & 67 & HAL \\
\hline 6 & $\mathrm{~F}$ & 53 & 26 & Lung & Pericardium & Dys & 81 & AMT/BRT (0.25mg/day) \\
\hline 7 & M & 50 & 12 & Stomach & Peritoneum $\cdot$ Lymph node & $\mathrm{MBO} \cdot$ Pain & 1185 & - \\
\hline 8 & M & 46 & 10 & Pharynx & - & Anxietry & 177 & KET \\
\hline 9 & $\mathrm{~F}$ & 54 & 3 & Stomach & Pleura $\cdot$ Peritoneum & Dys $\cdot$ Pain & 0 & - \\
\hline 10 & M & 76 & 23 & Colon & Liver & MBO & 55 & - \\
\hline 11 & M & 51 & 16 & Ovary & Kidney & $\mathrm{MBO} \cdot$ Pain & 348 & KET \\
\hline 12 & $\mathrm{~F}$ & 94 & 16 & Esophagus & - & Dys & 0 & - \\
\hline 13 & $\mathrm{~F}$ & 53 & 12 & uterus & Lung & Dys $\cdot$ Pain & 308 & $\mathrm{KET} / \mathrm{HAL} / \mathrm{PHB}$ \\
\hline 14 & $\mathrm{~F}$ & 67 & 10 & Breast & Pleura & Dys $\cdot \mathrm{Ple}$ & 162 & KET \\
\hline 15 & $\mathrm{~F}$ & 85 & 35 & Ovary & Peritoneum & Dysphagia & 0 & $\mathrm{HAL}$ \\
\hline 16 & M & 58 & 10 & Rectum & Liver & $\mathrm{MBO} \cdot$ Pain & 416 & $\mathrm{KET} / \mathrm{HAL}$ \\
\hline 17 & M & 76 & 30 & Porta hepatis & Lung & Pain $\cdot$ Nau & 120 & - \\
\hline 18 & $\mathrm{~F}$ & 51 & 7 & Rectum & Bone $\cdot$ Intrapelvic & Fatigue & 24 & HAL \\
\hline 19 & $\mathrm{~F}$ & 59 & 6 & Ovary & Liver $\cdot$ Peritoneum $\cdot$ Skin & $\mathrm{Asc} \cdot \mathrm{MBO} \cdot \mathrm{Nau}$ & 392 & $\mathrm{HAL}$ \\
\hline
\end{tabular}

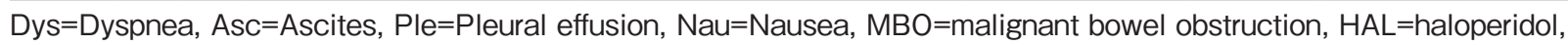
$\mathrm{LEV}=$ levomepromazine, $\mathrm{BRM}=$ bromazepam, $\mathrm{BRT}=$ brotizolam, $\mathrm{KET}=$ ketamine, $\mathrm{PHB}=$ phenobarbital, $\mathrm{AMT}=$ amitriptyline

in the study did not become oversedated and could awaken in the morning for at least 3 days. The daily infusion rate of midazolam was recorded for each of the 19 patients only during the days that the patients did not become oversedated and could awaken in the morning. Patient characteristics are shown in Table 1.

The infusion rate was adjusted by bedside nurses who monitored the patients' vital signs and sedation levels at 1 or 2 hour intervals during the night. The rate was adjusted to maintain a sedation level of 3 to 5 (according to Ramsey's sedation scale [13]), at which the patients did not respond to slight stimuli, from the induction of sleep to midnight, and a sedation level of 2 to 3 , at which the patients respond to slight stimuli, in the early morning.

The infusion rate of midazolam that was used for the longest period each day and resulted in appropriate sleep for each patient was defined as the "maintenance dose".

\section{Statistical analysis}

Changes in the maintenance doses over time were analyzed by a mixed-effects model using NONMEM software (Version $\mathrm{V}$ level 1.0; Globomax LLC, MD, USA).

Time dependency of the changes in maintenance doses was examined using 2 models: one was a model which assumed that maintenance doses were constant irrespective of time $(\mathrm{Y}=\theta 1)$, and the other model assumed that maintenance doses changed with time in a linear manner $(Y=\theta 2 \mathrm{t}+\theta 1)$. The deviances (log likelihood) calculated for the two models were then compared.

We next examined the influence of age, dose of opioids administered, serum creatinine level, serum ALT level, gender, haloperidol administration, ketamine administration, dyspnea, bone metastasis and pain on maintenance doses.

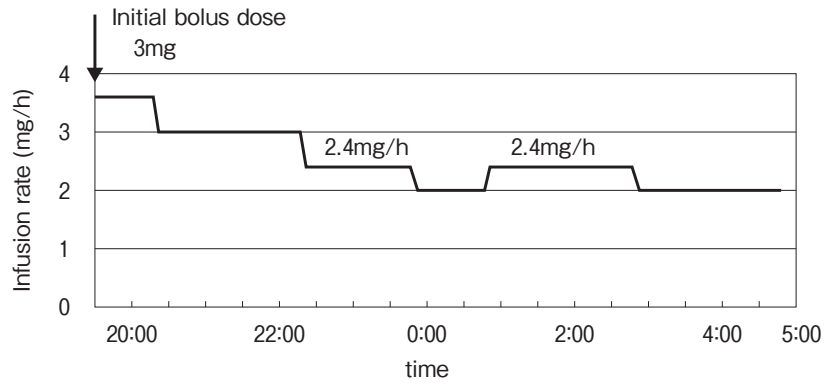

Fig 1. Midazolam maintenance dose ${ }^{\star}$ of patient No. 9

*Maintenance dose is the infusion rate which is used for the longest time in one day to get an adequate level of sedation. For example, the maintenance dose on the patient No. 9 at night on the day 1 was $2.4 \mathrm{mg} / \mathrm{h}$.

The representative dose of opioids administered was based on the maximum dose in the study period for each patient and was expressed in relation to an equivalent dose of morphine. Fentanyl patch $(25 \mu \mathrm{g} / \mathrm{h})$ and $50 \mathrm{mg} /$ day oral morphine were defined as the equivalent of $25 \mathrm{mg}$ /day parenterally administered morphine [14].

\section{Results}

Figure 1 shows the change in the infusion rate of midazolam in patient 9 from the day 1 to the day 2 . While maintaining the patient in an appropriate sedative condition (level 3 to 5 according to Ramsey's sedation scale), the infusion rate was sequentially decreased, and the rate was maintained to achieve light sedative condition (level 2 to 3 ) in the early morning. The infusion rate at which midazolam was infused for the longest period from the night to the morning was defined as the "maintenance dose" for that resulted in an appropriate sleep condition. 
Table 2. Population analysis of midazolum maintenance dose

\begin{tabular}{lcccccc}
\hline & OBJ & $\theta 1$ & $\theta 2$ & $\omega 1$ & $\omega 2$ & $\sigma$ \\
\hline $\mathrm{Y}=\theta 1$ & 168.77 & 2.39 & & 1.05 & & 0.75 \\
$\mathrm{Y}=\theta 2 \mathrm{t}+\theta 1$ & 150.05 & 2.11 & 0.039 & 0.49 & 0.96 & 0.71 \\
\hline
\end{tabular}

OBJ ; Objective Function

$\theta 1$; mean of maintenance dose

$\theta 2$; mean of slope

$\omega 1$; interindividual standard deviation of maintenance dose

$\omega 2$; interindividual standard deviation of slope

$\sigma$; intraindividual standard deviation of maintenance dose

$\mathrm{t}$; time (days) during midazolam treatment

During the study, the mean assessment period of midazolam administration (days), mean total time of midazolam infusion ( $h /$ day), and mean opioid dose equivalent to parenteral morphine in 19 patients were $16.5 \pm 10.3$ days, $8.76 \pm 1.06 \mathrm{~h} /$ day, and $181.3 \pm$ $280.2 \mathrm{mg}$, respectively (Table 1). The mean dose and infusion rate of midazolam on the first day of administration were $14.5 \pm 8.5$ (5 - 34) $\mathrm{mg} /$ day and $1.64 \pm 0.87(0.8-3.6) \mathrm{mg} / \mathrm{h}$, respectively, and the dose of midazolam at infusion for the induction of sedation was $2.16 \pm 1.39(0.7-5.0) \mathrm{mg}$. The mean maximum dose of midazolam and the maximum midazolam infusion rate were $47.9 \pm 45.0$ (10 200) $\mathrm{mg} /$ day and $5.67 \pm 6.97(1.2-30) \mathrm{mg} / \mathrm{h}$, respectively (data not shown).

The maintenance doses in 19 patients are shown in Figure 2. The maintenance doses in 2 patients (patient 3 and 4) were rapidly increased. Patient 3 was a 47 -year-old woman with a diagnosis of lung cancer. She had complications of multiple metastases in the lungs bilaterally, carcinomatous pericarditis, carcinomatous pleurisy, and metastasis to lumbuses. She was administered morphine at doses of 60 to $80 \mathrm{mg}$ orally because of lumbago and chest pain. She was also given $11 \mathrm{mg} /$ day of haloperidol because of nausea and vomiting, which were considered to be adverse effects of morphine. From day 31 onwards after starting midazolam treatment, midazolam was administered in the daytime, as well as in the evening, for 5 days before she died. The maximum dose of midazolam achieved was $492 \mathrm{mg} /$ day.

Patient 4 was a 57-year-old woman with a diagnosis of ovarian cancer with metastasis to the peritoneum, liver, and lymph nodes. She could not take oral medicine due to filling of ascites in the abdominal cavity. She had been medicated for depression for the past 2 years with benzodiazepines and levomepromazine. She was administered approximately $30 \mathrm{mg}$ /day of morphine, and was also administered $5 \mathrm{mg} /$ day of haloperidol for the treatment of nausea due to primary cancer. From 12 days after starting midazolam, she was treated to induce sedation even in the daytime, with intravenous midazolam (288 mg/day) and haloperidol (18 mg/day) for 11 days until she died.

We excluded the maintenance dose data of 2 patients from the statistical analysis because the doses clearly increased and the statistical analysis used in this study would otherwise be confounded. With the data obtained from the other 17 patients, timedependent changes in maintenance doses were statistically analyzed

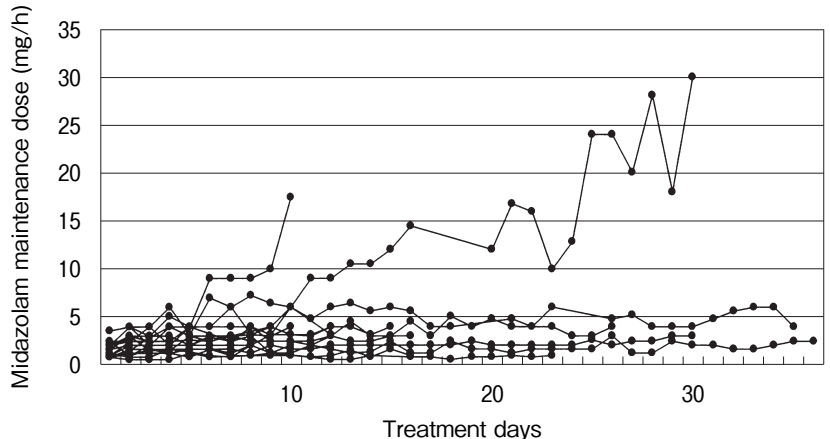

Fig 2. Midazolam maintenance dose of 19 patients during treatment

Table 3. Evaluation of covariates for midazolam maintenance dose

\begin{tabular}{cccccc}
\hline & $\theta 1$ & $\theta 2$ & OBJ & $\Delta$ OBJ & $P$ Value \\
\hline $\mathrm{Y}=\theta 1$ & 2.39 & & 168.77 & & \\
$\mathrm{Y}=\theta 1 \cdot(1+\theta 2 \cdot \mathrm{AGE})$ & 1.72 & 0.01 & 168.24 & 0.53 & $\mathrm{NS}$ \\
$\mathrm{Y}=\theta 1 \cdot(1+\theta 2 \cdot \mathrm{CRE})$ & 3.00 & -0.90 & 167.17 & 1.60 & $\mathrm{NS}$ \\
$\mathrm{Y}=\theta 1 \cdot(1+\theta 2 \cdot \mathrm{ALT})$ & 2.43 & 0.00 & 168.75 & 0.02 & $\mathrm{NS}$ \\
$\mathrm{Y}=\theta 1 \cdot(1+\theta 2 \cdot \mathrm{SEX})$ & 2.50 & -0.09 & 168.49 & 0.28 & $\mathrm{NS}$ \\
$\mathrm{Y}=\theta 1 \cdot(1+\theta 2 \cdot \mathrm{HAL})$ & 2.22 & 0.22 & 160.36 & 8.41 & $\mathrm{P}<0.005$ \\
$\mathrm{Y}=\theta 1 \cdot(1+\theta 2 \cdot \mathrm{KET})$ & 2.40 & 0.00 & 168.76 & 0.01 & $\mathrm{NS}$ \\
$\mathrm{Y}=\theta 1 \cdot(1+\theta 2 \cdot \mathrm{DYS})$ & 2.43 & -0.04 & 168.72 & 0.05 & $\mathrm{NS}$ \\
$\mathrm{Y}=\theta 1 \cdot(1+\theta 2 \cdot \mathrm{BON})$ & 2.59 & -0.30 & 166.35 & 2.42 & $\mathrm{NS}$ \\
$\mathrm{Y}=\theta 1 \cdot(1+\theta 2 \cdot \mathrm{PAI})$ & 2.52 & -0.14 & 168.19 & 0.58 & $\mathrm{NS}$ \\
$\mathrm{Y}=\theta 1+\theta 2 \cdot \mathrm{OPI}$ & 2.38 & 0.00 & 168.76 & 0.01 & $\mathrm{NS}$ \\
\hline $\mathrm{AGE}$
\end{tabular}

$\mathrm{AGE}=$ age, $\mathrm{CRE}=$ serum creatinin,

$A L T=$ alanine aminotransferase, $\operatorname{SEX}=\operatorname{sex}(\mathrm{M} / \mathrm{F}=1 / 0)$,

$\mathrm{HAL}=$ haloperidol $(\mathrm{Yes} / \mathrm{No}=1 / 0)$,

$\mathrm{KET}=$ ketamine $(\mathrm{Yes} / \mathrm{No}=1 / 0)$,

$\mathrm{DYS}=$ dyspnea $(\mathrm{Yes} / \mathrm{No}=1 / 0)$,

$\mathrm{BON}=$ bone metastasis $(\mathrm{Yes} / \mathrm{No}=1 / 0)$,

$\mathrm{PAI}=$ pain $(\mathrm{Yes} / \mathrm{No}=1 / 0), \mathrm{OPI}=$ opioid dose

using a mixed-effects model. The results are shown in Table 2. $Y$ is the infusion rate of midazolam and $t$ is the time after starting midazolam administration (days). The analysis demonstrated that the results with equation $Y=\theta 2 t+\theta 1$ did not differ significantly as compared with those with equation $\mathrm{Y}=\theta 1$, indicating there was no time-dependent change in the maintenance dose, and the mean maintenance dose was $2.39 \mathrm{mg} / \mathrm{h}$.

Factors affecting $\theta 1$ were then analyzed using a model which assumed that the maintenance dose was constant irrespective of time $(\mathrm{Y}=\theta 1)$. The equation actually used was $\mathrm{Y}=\theta 1(1+\theta 2 \mathrm{P})$, where $P$ indicates a factor possibly affecting $\theta 1$. The results, shown in Table 3 , demonstrated that the maintenance dose was significantly greater in patients treated with haloperidol than in patients not treated with haloperidol $(\mathrm{p}<0.005)$.

\section{Discussion}

Physical and psychological distress caused by sleep disturbance make the patients' last days unbearable; therefore, sleep of sufficient quality and quantity is important for these patients. 
There have been a few reports on intravenous administration of midazolam in terminal cancer patients for the treatment of sleep disturbance. However, since intravenous midazolam has been widely used in the ICU setting for sedation, similar methodologies and dosages might be adaptable for use in palliative care of terminal cancer patients. In the ICU, doses of midazolam between 0.03 $\mathrm{mg} / \mathrm{kg}$ and $0.06 \mathrm{mg} / \mathrm{kg}$ have been recommended for induction of sedation [8]. The infusion rates of midazolam have varied greatly among studies depending on the type and dose of co-medicated narcotics and the duration of midazolam treatment. Previous studies have reported infusion rates of $0.092 \pm 0.028 \mathrm{mg} / \mathrm{kg} / \mathrm{h}[5], 0.036 \pm$ $0.054 \mathrm{mg} / \mathrm{kg} / \mathrm{h} \mathrm{[6]}$, and $0.08 \pm 0.01 \mathrm{mg} / \mathrm{kg} / \mathrm{h} \mathrm{[7]} \mathrm{for} \mathrm{relatively} \mathrm{short-}$ term sedation. Although the exact measurement of body weight was not possible in most of the patients in the present study, using an estimated body weight of $50 \mathrm{~kg}$ the calculated dose of midazolam for sleep induction was $0.043 \pm 0.028 \mathrm{mg} / \mathrm{kg}$, and the infusion rate on the first day of midazolam treatment was $0.031 \pm 0.017 \mathrm{mg} / \mathrm{kg} / \mathrm{h}$.

The lag time between the end of the infusion and patients' awakening also varied greatly among the studies [4-7]. Miller et al. [6] reported that post-operative patients infused with midazolam for 16 hours maintained a sedation level of 3 to 5 according to Ramsey's sedation scale. In that study, patients given midazolam at a higher induction dose and a higher initial infusion rate achieved higher blood concentrations of midazolam and longer times to awakening after the end of infusion. The results might indicate that, using clinical observations alone, it is difficult to decide the lowest infusion rate for a desired level of sedation. Therefore, it may be best to maintain a relatively high sedation level from the time induction of sleep until midnight and a relatively low level in the early morning.

It is assumed that if midazolam is rapidly infused to induce sedation, the blood concentration of midazolam immediately reaches a steady state at which the sedation level is maintained. Therefore, as a representative index of the midazolam infusion rate for our analyses, we used the infusion rate that was used for the longest period per day in each patient, rather than the mean infusion rate.

Statistical analysis with NONMEM software can simultaneously analyze parameters expressing the relationship between changes in the maintenance dose and time sequence in the patients as a whole and parameters expressing intra- and inter-individual variations in the maintenance dose.

Among the 19 patients included in this study, 2 patients showed particularly rapid increases in their maintenance doses, although the cause was uncertain. Data for maintenance doses in 2 patients who developed tolerance differed substantially from these of the other 17 patients and were therefore excluded so as not to confound the statistical analysis of data from this relatively small sample population. The maintenance dose and time sequence did not show a significant relationship among the 17 patients. Tolerance to midazolam may not be developed when it is administered by repeated intermittent short-term infusion.

The remaining 17 patients were also used for the analysis of factors affecting the maintenance dose. Age was not a covariate. It has been reported that in the ICU the dose [15] and infusion rate [9] decrease with age when the sedation level is kept at the same level for all patients, and it has also been reported that pharmacological reactivity to hypnotics increases in aged people $[9,16]$. However, an age-dependent decrease in the maintenance dose was not observed in this study, probably because the subjects were relatively old and relatively less varied in age (46 - 94 years of age), or because the pharmacokinetic capacity varied widely among the subjects due to their varied disease conditions.

It has been reported that the dose of morphine administered after surgery can be reduced when midazolam is coadministered $[3,6]$. We found that the dose of opioids was not a covariate, although it did vary widely among subjects, as shown in Table $1(0$ - $1185 \mathrm{mg}$ equivalent to parenterally administered morphine). Coadministration of opioids, for the suppression of cancer pain, did not seem to enhance the sedative effect of midazolam.

Administration of haloperidol was detected as a factor associated with increased maintenance doses of midazolam. This is assumed to be attributable to the pharmacological action of haloperidol and the pathological condition of patients given haloperidol. It has previously been shown, based on studies in animals, that haloperidol interacts with $\mathrm{GABA}_{\mathrm{A}}$ receptors [17], which could affect the pharmacological action of benzodiazepines. A possible pathological factor is the strong physical and mental suffering of terminal cancer patients treated with haloperidol for pain, nausea and delirium. Haloperidol was given to relieve these symptoms, but it appeared that it might not have been sufficiently effective. It is also possible that organic neuropsychological changes in the patients might affect the maintenance dose.

The study subjects were patients with terminal cancer whose average survival time was $24.6 \pm 12.7$ days. Midazolam treatment for nocturnal sedation was sufficiently safe and effective in these patients without problems from respiratory suppression or withdrawal, although a slight carry-over of the hypnotic effect was observed. In addition, an abrupt increase in the dose of midazolam did not occur in most of the patients. Midazolam infusion only in the nighttime provides sufficient sleep for patients, so that they may be able to spend their remaining days in comfort while eliminating or delaying the need for terminal sedation. Furthermore, this method is also useful for safely introducing continuous sedation because daytime midazolam infusion can be gradually combined with nighttime infusion.

Some limitation of this study should be mentioned. This was an observational study of a small number of patients, thus the result of statistical analysis have to be dealt with cautiously. Also the maintenance dose might vary as adjusting the infusion rate and visiting intervals to the patients were left to the discretion of the nursing staff. There is a clear need for additional trials of investigating the most safe and effective way to use midazolam for nocturnal sedation.

In conclusion, the records of 19 terminal cancer patients treated with midazolam by continuous intravenous infusion for induction of nocturnal sedation were surveyed. A rapid increase in the maintenance dose was observed in 2 patients. Among the other 17 patients, the maintenance doses analyzed using NONMEM software 
were statistically constant over time within the investigation period. It would suggest that tolerance may not be induced by intermittent administration of midazolam. A prospective study is needed to further define the role of midazolam as an agent for nocturnal sedation.

\section{Acknowledgments}

We would like to thank Dr Narufumi Sekido, Dr Munehiro Shimada and the Nursing staff of the palliative care unit in Kyuseigun Kiyose Hospital.

\section{References}

1) O'Donnell JF. Insomnia in cancer patients. Clin Cornerstone 2004; 6 Suppl 1D: S6-14.

2) Matsuo N, Morita T. Intravenous infusion of midazolam and flunitrazepam for insomnia on Japanese pallative care units. J Pain Symptom Manage 2005; 30: 301-302.

3) Westphal LM, Cheng EY, White PF, et al. Use of midazolam infusion for sedation following cardiac surgery. Anesthesiology 1987; 67: 257-262.

4) Shelly MP, Sultan MA, Bodenham A, et al. Midazolam infusions in critically ill patients. Eur J Anaesthesiol 1991; 8:21-27.

5) Roekaerts PM, Huygen FJ, de Lange S. Infusion of propofol versus midazolam for sedation in the intensive care unit following coronary artery surgery. J Cardiothorac Vasc Anesth 1993; 7: 142-147.

6) Miller DR, Martineau MD, Hull KA, et al. Optimizing sedation following major vascular surgery: a double-blind study of midazolam administered by continuous infusion. Can J Anaesth 1994; 41: 782-793.

7) Carrasco G, Cabre L, Sobrepere G, et al. Synergistic sedation with propofol and midazolam in intensive care patients after coronary artery bypass grafting. Crit Care Med 1998; 26: 844-851.

8) Hanaoka K, Namiki A, Dohi S, et al. A dose-ranging study of midazolam for postoperative sedation of patients: a randomized, double-blind, placebo-controlled trial. Crit Care Med 2002; 30: 1256-1260.

9) Bremer F, Reulbach U, Schwilden H, et al. Midazolam Therapeutic drug monitoring in intensive care sedation: a 5-year survey. Ther Drug Monit 2004; 26: 643-649.

10) Burke AL, Diamond PL, Hulbert J, et al. Terminal restlessness-its management and the role of midazolam. Med J Aust 1991; 155: 485-487.

11) Ramani S, Karnad AB. Long-term subcutaneous infusion of midazolam for refractory delirium in terminal breast cancer. South Med J 1996; 89: 1101-1103.

12) Morita $T$, Tei $Y$, Inoue $S$. Correlation of the dose of midazolam for symptom control with administration periods: the possibility of tolerance. J Pain Symptom Manage 2003; 25: 369-375.

13) Ramsay MA, Savege TM, Simpson BR, et al. Controlled sedation with alphaxalone-alphadolone. BMJ 1974; 2: 656-659.

14) Doyle D, Hanks G, Cherny N, et al. Opioid analgesic therapy. In: Doyle D, Hanks GCW, MacDonald N, eds. Oxford textbook of Palliative Medicine, 3nd ed. New York: Oxford University Press, 2004; 316-341.

15) Parlak M, Parlak I, Erdur B, et al. Age effect on efficacy and side effects of two sedation and analgesia protocols on patients going through cardioversion: a randomaized clinical trial. Acad Emergency Medi 2006; 13: 493-499.

16) Jacobs JR, Reves JG, Marty J, et al. Aging increases pharmacodynamic sensitivity to the hypnotic effects of midazolam. Anesth Analg 1995; 80: 143-148.

17) Zink M, Schmitt A, May B, et al. Differential effects of longterm treatment with clozapine or haloperidol on GABAA receptor 


\title{
ホスピスの末期がん患者における夜間睡眠薬としての ミダゾラムの投与
}

\author{
古宇田裕子 ${ }^{1)}$,, 花田和彦 ${ }^{2)}$, 緒方宏泰 ${ }^{2)}$ \\ 1) 明治薬科大学大学院臨床薬学専攻 (元 救世軍清瀬病院薬剤科 ) \\ 2) 明治薬科大学薬剤学 \\ 3) 大木記念女性のための菊池がんクリニック
}

\begin{abstract}
末期がん患者における睡眠障害に対して, ミダゾラムの持続静脈投与が行われている. しかし, 適切な投与量, 投与方法に関 する報告は少なく, また, ミダゾラムの耐性の可能性についてもいくつかの報告がある. 本研究では, ホスピスに入院し, 夜 間の睡眠を目的としてミダゾラムを処方された患者 19 名のミダゾラムの投与速度を後向きに調査した. それぞれの患者で 1 日ごとに最も長時間用いられた投与速度を “維持投与速度” として, ミダゾラム投与期間における変化と変動要因につい て検討した. 2 名の患者でミダゾラムの投与量は著しく増大した.しかし, 他の 17 名では, 時間経過に対する変化は統計的 に認められず, ミダゾラムの夜間のみの間欠投与においては耐性が起こらない可能性がある. 変動要因としてハロペリドー ルを投与している患者で維持投与速度の増大が認められた。
\end{abstract}

Keywords: ミダゾラム, 末期がん, ホスピス, 鎮静, 静脈投与

表 1 患者背景

\begin{tabular}{|c|c|c|c|c|c|c|c|c|}
\hline 患者No. & 性別 & 年齢 & 調査期間 & 原発巣 & 転移部位 & 症候 - 症状 & $\begin{array}{c}\text { オピオイド } \\
\text { 最高投与量 } \\
\text { (mg/日) }\end{array}$ & 併用された精神神経薬 \\
\hline 1 & M & 78 & 7 & 肺 & 骨 & 呼吸困難 & 0 & - \\
\hline 2 & M & 78 & 36 & 甲状腺 & 骨 & 腹水·疼痛 & 25.5 & - \\
\hline 3 & $\mathrm{~F}$ & 47 & 30 & 肺 & 心膜・胸膜 & 呼吸困難 $\cdot$ 胸水 $\cdot$ 喘鳴 $\cdot$ 嘔気 & 40 & HAL/LEV/BRM (3mg/日) \\
\hline 4 & $\mathrm{~F}$ & 57 & 10 & 卵巣 & 腹膜 & 腹水 $\cdot$ 嘔気 & 45 & HAL/BRM (3mg/日) \\
\hline 5 & M & 72 & 15 & 胃 & 腹膜 & 腹水 & 67 & HAL \\
\hline 6 & $\mathrm{~F}$ & 53 & 26 & 肺 & 心膜 & 呼吸困難 & 81 & AMT/BRT (0.25mg/日) \\
\hline 7 & M & 50 & 12 & 胃 & 腹膜 & 腸閉塞 · 疼痛 & 1185 & - \\
\hline 8 & M & 46 & 10 & 上咽頭 & - & 不安 & 177 & KET \\
\hline 9 & $\mathrm{~F}$ & 54 & 3 & 胃 & 胸膜・腹膜 & 呼吸困難・疼痛 & 0 & - \\
\hline 10 & M & 76 & 23 & 大腸 & 肝 & 腸閉塞 & 55 & - \\
\hline 11 & M & 51 & 16 & 卵巣 & 腎 & 腸閉塞 · 疼痛 & 348 & KET \\
\hline 12 & $\mathrm{~F}$ & 94 & 16 & 食道 & - & 呼吸困難 & 0 & - \\
\hline 13 & $\mathrm{~F}$ & 53 & 12 & 子宮 & 肺 & 呼吸困難 ・ 疼痛 & 308 & $\mathrm{KET} / \mathrm{HAL} / \mathrm{PHB}$ \\
\hline 14 & $\mathrm{~F}$ & 67 & 10 & 乳 & 胸膜 & 呼吸困難 · 喘鳴 ·胸水 & 162 & KET \\
\hline 15 & $\mathrm{~F}$ & 85 & 35 & 卵巣 & 腹膜 & 嚥下困難 & 0 & $\mathrm{HAL}$ \\
\hline 16 & $M$ & 58 & 10 & 直腸 & 肝 & 腸閉塞・疼痛 & 416 & $\mathrm{KET} / \mathrm{HAL}$ \\
\hline 17 & M & 76 & 30 & 肝門 & 肺 & 疼痛・嘔気 & 120 & - \\
\hline 18 & $\mathrm{~F}$ & 51 & 7 & 直腸 & 骨盤内・骨 & 全身倦怠感 & 24 & HAL \\
\hline 19 & $\mathrm{~F}$ & 59 & 6 & 卵巣 & 肝 - 腹膜 - 皮膚 & 腹水 · 腸閉塞 - 嘔気 & 392 & HAL \\
\hline
\end{tabular}

$\mathrm{HAL}=$ ハロペリドール, LEV=レボメプロマジン, BRM=ブロマゼパム, BRT=ブロチゾラム, KET=ケタミン, $\mathrm{PHB}=$ フェノバルビタール, $\mathrm{AMT}=$ アミトリプチリン 


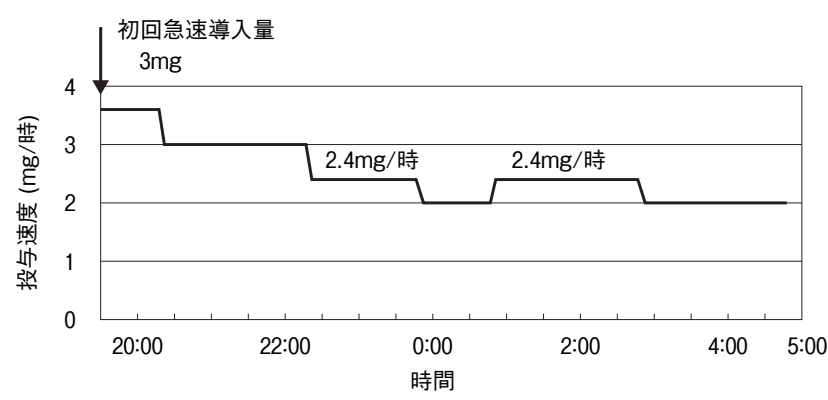

図 1 夜間のミダゾラムの投与速度の変化の例 (症例9) 夜間に最も長時間用いられた投与速度を“維持投与速度”とした。 症例 9 の投与 1 日目の “維持投与速度”は2.4m/ 時であった。

表 2 ミダゾラムの維持投与速度の母集団解析の結果 (17 例)

\begin{tabular}{lcccccc}
\hline & OBJ & $\theta 1$ & $\theta 2$ & $\omega 1$ & $\omega 2$ & $\sigma$ \\
\hline $\mathrm{Y}=\theta 1$ & 168.77 & 2.39 & & 1.05 & & 0.75 \\
$\mathrm{Y}=\theta 2 \mathrm{t}+\theta 1$ & 150.05 & 2.11 & 0.039 & 0.49 & 0.96 & 0.71
\end{tabular}

OBJ ; Objective Function

$\theta 1 ;$ 維持投与速度の平均値

$\theta 2 ;$ 傾きの平均値

$\omega 1 ;$ 維持投与速度の個体間標準偏差

$\omega 2 ;$ 傾きの個体間標準偏差

$\sigma ;$ 維持投与速度の個体内標準偏差

$\mathrm{t}$; ミダゾラム投与日数

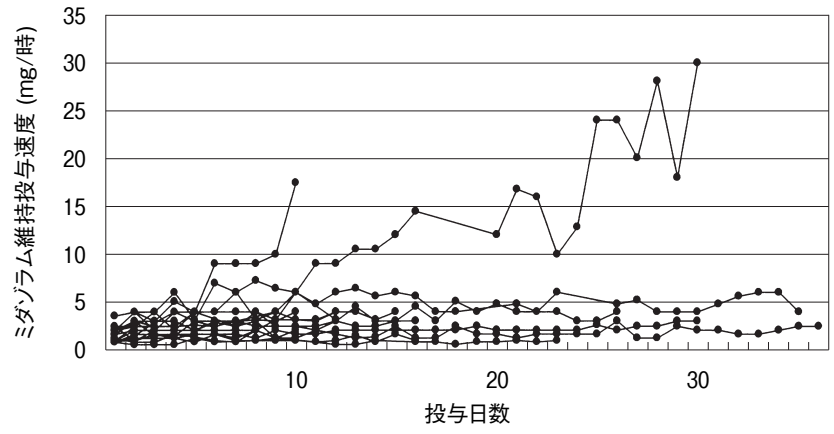

図 219 例のミダゾラムの維持投与速度の変化

表 3 ミダゾラムの維持投与速度に対する変動要因 (17 例)

\begin{tabular}{cccccc}
\hline & $\theta 1$ & $\theta 2$ & OBJ & $\Delta$ OBJ & $P$ Value \\
\hline $\mathrm{Y}=\theta 1$ & 2.39 & & 168.77 & & \\
$\mathrm{Y}=\theta 1 \cdot(1+\theta 2 \cdot \mathrm{AGE})$ & 1.72 & 0.01 & 168.24 & 0.53 & $\mathrm{NS}$ \\
$\mathrm{Y}=\theta 1 \cdot(1+\theta 2 \cdot \mathrm{CRE})$ & 3.00 & -0.90 & 167.17 & 1.60 & $\mathrm{NS}$ \\
$\mathrm{Y}=\theta 1 \cdot(1+\theta 2 \cdot \mathrm{ALT})$ & 2.43 & 0.00 & 168.75 & 0.02 & $\mathrm{NS}$ \\
$\mathrm{Y}=\theta 1 \cdot(1+\theta 2 \cdot \mathrm{SEX})$ & 2.50 & -0.09 & 168.49 & 0.28 & $\mathrm{NS}$ \\
$\mathrm{Y}=\theta 1 \cdot(1+\theta 2 \cdot \mathrm{HAL})$ & 2.22 & 0.22 & 160.36 & 8.41 & $\mathrm{P}<0.005$ \\
$\mathrm{Y}=\theta 1 \cdot(1+\theta 2 \cdot \mathrm{KET})$ & 2.40 & 0.00 & 168.76 & 0.01 & $\mathrm{NS}$ \\
$\mathrm{Y}=\theta 1 \cdot(1+\theta 2 \cdot \mathrm{DYS})$ & 2.43 & -0.04 & 168.72 & 0.05 & $\mathrm{NS}$ \\
$\mathrm{Y}=\theta 1 \cdot(1+\theta 2 \cdot \mathrm{BON})$ & 2.59 & -0.30 & 166.35 & 2.42 & $\mathrm{NS}$ \\
$\mathrm{Y}=\theta 1 \cdot(1+\theta 2 \cdot \mathrm{PAI})$ & 2.52 & -0.14 & 168.19 & 0.58 & $\mathrm{NS}$ \\
$\mathrm{Y}=\theta 1+\theta 2 \cdot \mathrm{OPI}$ & 2.38 & 0.00 & 168.76 & 0.01 & $\mathrm{NS}$ \\
\hline $\mathrm{AGE}$
\end{tabular}

$A G E=$ 年齢, $C R E=$ 血清クレアチニン值, $A L T=$ 血清 $A L T$ 值 $S E X=$ 性別 ( 男 / 女 $=1 / 0)$,

$H A L=$ ハロペリドール (有 / 無 $=1 / 0)$,

$\mathrm{KET}=$ ケタミン (有 / 無 $=1 / 0)$,

$D Y S=$ 呼吸困難 $($ 有 $/$ 無 $=1 / 0)$,

$B O N=$ 骨転移 ( 有 $/$ 無 $=1 / 0$ ), PAI =疼痛 (有 $/$ 無 $=1 / 0$ ), $\mathrm{OPI}=$ オピオイド投与量 